\title{
POLEMIKE
}

\section{VELIKA IN MALA ZAČETNICA TER DRUGI PROBLEMI ZAPISOVANJA SLOVENSKIH ZEMLJEPISNIH IMEN}

\author{
AVTORJA
}

dr. Drago Kladnik

Znanstvenoraziskovalni center Slovenske akademije znanosti in umetnosti, Geografski inštitut Antona Melika, Gosposka ulica 13, SI - 1000 Ljubljana, Slovenija

drago.kladnik@zrc-sazu.si

\section{dr. Drago Perko}

Znanstvenoraziskovalni center Slovenske akademije znanosti in umetnosti, Geografski inštitut Antona Melika, Gosposka ulica 13, SI - 1000 Ljubljana, Slovenija

drago@zrc-sazu.si

DOI: $10.3986 / G V 90207$

UDK: 811.163.6’373.21

COBISS: 1.02

\section{IZVLEČEK}

\section{Velika in mala začetnica ter drugi problemi zapisovanja slovenskih zemljepisnih imen}

Tokratno, drugo razpravo o bolj zapletenih vidikih in primerih rabe slovenskih zemljepisnih imen namenjamo predvsem rabi velike in male začetnice $v$ večbesednih slovenskih zemljepisnih imenih, slovenjenju večbesednih tujih zemljepisnih imen, večbesednim imenom delov naselij (mest in vasi) ter rabi velike in male začetnice pri vzdevkih oziroma nadomestnih imenih (na primer črna celina, dežela tisočerih jezer). Na koncu predstavljamo poenostavitve pri pisanju zemljepisnih imen, kot jih predvideva nastajajoči novi slovenski pravopis.

\section{KLJUČNE BESEDE}

geografija, jezikoslovje, zemljepisna imena, sporna imena, standardizacija, velika in mala začetnica, pravopis, slovenščina, Slovenija

\section{ABSTRACT}

\section{Capitalization and other issues in writing Slovenian geographical names}

This second discussion on more complex aspects and examples of using Slovenian geographical names is primarily dedicated to capitalization in multiword Slovenian geographical names, Slovenianizing multiword foreign geographical names, multiword names of parts of towns and villages, and capitalization of nicknames or other descriptive names (e.g., Dark Continent, land of a thousand lakes). It concludes by presenting simplifications in how geographical names should be written as defined in the new Slovenian normative guide being prepared.

\section{KEY WORDS}

geography, linguistics, geographical names, disputed names, standardization, capitalization, orthography, Slovene, Slovenia

Uredništvo je prispevek prejelo 10. oktobra 2018. 


\section{Uvod}

Prispevek je nadaljevanje članka iz 89. letnika Geografskega vestnika (Kladnik in Perko 2017), v katerem je bila predstavljena predvem problematika slovenskih imen držav in drugih slovenskih eksonimov.

Raba zemljepisnih imen je v slovenskem jeziku vse bolj enotna (Preglednica eksonimov 2014), pogledi nanjo pa vse bolj usklajeni (Kladnik 2007). Kljub temu imamo zaradi nestrokovnega ali vsaj ne najbolj posrečenega slovenjenja tujih zemljepisnih imen, nedorečenih pravopisnih pravil, nepoznavanja procesa standardizacije zemljepisnih imen, pa tudi splošnega nepoznavanja obravnavane tematike na tem področju še številne probleme (Kladnik 2006; Kladnik in Perko 2007; 2013; 2015; Kladnik in Bole 2012; Kladnik s sodelavci 2013; 2017; Klinar in Geršič 2014; Geršič 2017; Perko, Jordan in Komac 2017; Perko in Kladnik 2017).

Tudi mednarodna standardizacijska priporočila, ki slonijo na resolucijah Skupine izvedencev Združenih narodov za zemljepisna imena 'United Nations Group of Experts on Geographical Names' (UNGEGN), ki jo pri nas zastopa Komisija za standardizacijo zemljepisnih imen Vlade Republike Slovenije (KSZI VRS), so večkrat v nasprotju z jezikoslovno prakso in zakonitostmi jezika (Dobrovoljc in Jakop 2012). Problemov pa ni mogoče razreševati le v ozkih jezikoslovnih krogih, ampak je vse sprejemljive rešitve treba iskati v širši strokovni javnosti (Dobrovoljc in Jakop 2011).

Nekaj izboljšav predlagava tudi avtorja, ki sva o različnih problemih ustrezne rabe zemjepisnih imen pisala skupaj, posamič ali s sodelavci že v številnih člankih in monografijah. Ker sva tesno vpeta tudi v proces standardizacije zemljepisnih imen pri KSZI VRS in v delo Pravopisne komisije pri pripravi novega slovenskega pravopisa, upava, da bodo nakazane rešitve sestavni del nastajajočega posodobljenega pravopisa, predvsem kot ponazorilo k posameznim pravilom $\mathrm{v}$ njegovem slovarskem delu.

\section{Metodologija}

Način preučevanja zemljepisnih imen je opisan v lanskem Geografskem vestniku (Kladnik in Perko 2017), zato samo na kratko ponovimo, da smo za kvantifikacijo obravnavane tematike analizirali pogostnost pojavljanja obravnavanih zemljepisnih imen ter njihovih različic v jezikovnem korpusu $G i$ gafida, elektronski zbirki avtentičnih besedil, nastali po vnaprej določenih merilih in opremljeni z orodji, ki omogočajo večplastno iskanje jezikovnih podatkov. Korpus Gigafida vsebuje skoraj 1,2 milijarde besed iz obsežne zbirka slovenskih besedil najrazličnejših zvrsti, od dnevnih časopisov in revij do knjižnih publikacij vseh vrst zbirk (leposlovje, učbeniki, stvarna literatura), spletnih besedil, prepisov parlamentarnih govorov in podobno (Gigafida 2017). Pregledali smo tudi zapise v Jezikovni svetovalnici Inštituta za slovenski jezik Frana Ramovša ZRC SAZU in tam našli primere iz obravnavane tematike v tematskih področjih besedotvorje, etimologija, oblikoslovje, pravopis, kamor spadata tudi mala in velika začetnica, ter skladnja (Jezikovna svetovalnica 2017). Ti zapisi so izjemen pregled težav, s katerimi se srečujejo običajni ljudje pri pisanju zemljepisnih imen. Za analizo so pomembni tudi podatki o zastopanosti in načinu zapisa slovenskih zemljepinsih imen v najpomebnejših slovenskih atlasih sveta (Preglednica eksonimov 2014).

\section{Velika in mala začetnica}

V tokratnem nadaljevanju vsebine članka iz lanskega Geografskega vestnika (Kladnik in Perko 2017) predstavljamo poglavitne težave, dileme ter pomenske razločke pri rabi velike in male začetnice v večbesednih domačih in tujih zemljepisnih imenih, pa tudi pri zapisovanju vzdevkov oziroma nadomestnih zemljepisnih imen. 


\subsection{Večbesedna imena $z$ uveljavljeno enobesedno imensko različico}

Raba velike in male začetnice pri večbesednih zemljepisnih imenih, kjer je izrazito uveljavljeno tudi krajše, enobesedno ime, je neenotna. Tako na eni strani skladno z veljavnimi pravopisnimi pravili (Slovenski pravopis 2001) pišemo Goriška brda ali Brda (slika 1), Ljubljansko barje ali Barje, Notranjska reka ali Reka (znano je tudi ime Velika voda), Kočevski rog ali Rog in Suha krajina ali Krajina, vendar na drugi strani Matični Kras za celotno pokrajino Kras ter Komenski Kras, Divaški Kras, Sežanski Kras, Mirenski Kras in Tržaški Kras za njene sestavne dele, Bistriško Pohorje, Lovrenško Pohorje, Mariborsko Pohorje, Ribniško Pohorje, Slovenjgraško Pohorje in Zreško Pohorje za sestavne dele prostranega pogorja Pohorje, pa tudi Julijske Alpe, Karnijske Alpe, Bavarske Alpe, Bernske Alpe in Savojske Alpe za sestavne dele Alp ter Visoke Ture in Nizke Ture za sestavna dela Tur. V to skupino lahko vključimo tudi eksonim Hrvaško Zagorje, katerega endonimska oblika je Hrvatsko zagorje in je torej zapisana z malo začetnico.

Iz navedenega sledi, da se takrat, ko sta kratko in daljše ime alonima, torej alternativni imeni, pri daljšem poimenovanju občnoimenska sestavina piše z malo začetnico, kadar pa gre za sestavne dele večje pokrajinske enote, se vse besede pišejo z veliko začetnico. Pravilo je sicer na videz jasno, vendar njegova izvedba v praksi povzroča opazne težave. Problematično je tudi dejstvo, da se v večbesednih imenih z uveljavljeno enobesedno imensko različico občnoimenska sestavina razume izključno kot takšna, v krajši obliki pa ne tudi kot lastno ime, čemur pritrjuje zapis izpred nekaj let v Jezikovni svetovalnici (Bizjak Končar, Dobrovoljc in Weiss 2014): „Pri imenu Goriška brda res pogosto zasledimo zapis druge sestavine z veliko začetnico, saj ime pišemo tudi okrajšano, tj. samostojno kot Brda. Imena Goriška brda, Ljubljansko barje, ki jih našteva SP 2001 v členu 37, v okrajšani obliki neuradno pišemo z veliko začetnico. Če so del večbesednega nenaselbinskega imena, pa po pravopisu (člen 73) pišemo neprve sestavine z malo, če že same niso lastno ime. Brda niso lastno ime, kar dokazujeta zemljepisni imeni Primorska brda in Šavrinska brda .....

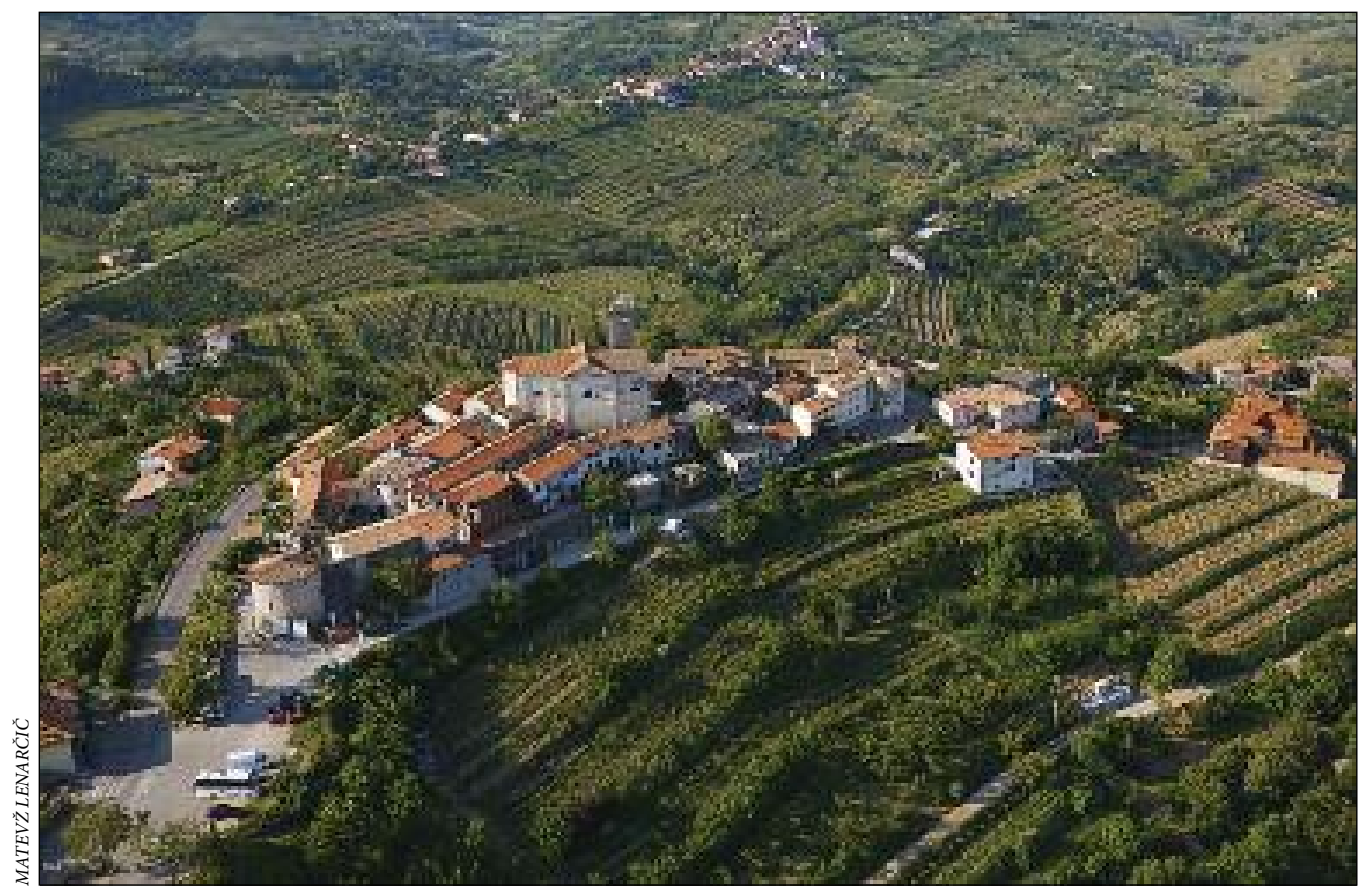

Slika 1: Slikovita vasica Šmartno je eden od najbolj prepoznavnih simbolov Goriških brd. 
Trditev, da Brda niso lastno ime, je najmanj za tamkajšnje prebivalce, torej Brike in Brice, zagotovo nesprejemljiva. Res je, da ima izraz brda tako kot gorice tudi občnoimensko konotacijo in se narečno uporablja za gričevje, vendar ob tem $\mathrm{z}$ rabo male začetnice zamujamo priložnost potrditve krajšega imena kot lastnega in tudi razlikovalne vloge med pokrajinami, v katerih imenih se pojavlja ta izraz. Ob Goriških brdih sta najbolj znani Vipavska brda in Koprska brda, prej bolj znana kot Šavrinska brda.

\section{2 "Slovenska Istra» ali »slovenska Istra»}

Trd oreh je tudi raba velike oziroma male začetnice pri pokrajinskem imenu Slovenska Istra oziroma slovenska Istra (slika 2) ali celo Istrska Slovenija (podobno kot Beneška Slovenija). Različen zapis namreč napeljuje na dva različna pojma, ki ju jezikovno slabše podkovani uporabniki med seboj sicer razlikujejo, vendar ju ne znajo ustrezno utemeljiti.

Raba velike začetnice namreč opredeljuje ime, ki se čedalje pogosteje uporablja za celotno pokrajino v skrajnem jugozahodnem delu Slovenije in zajema območje vzdolž slovenskega dela jadranske obale in njenega neposrednega gričevnatega zaledja. Kljub nekaterim pomislekom bi to ime lahko sčasoma postalo ustrezen nadomestek neenotnih poimenovanj tega dela države, za katerega se ob njem pojavljajo še imena Šavrini, Šavrinska brda oziroma Šavrinsko gričevje, Koprsko oziroma Koprščina (Vodopivec 2000), Koprsko Primorje, Obala (Gams 1990) in kot najnovejše Koprska brda (Kladnik 1996; Repolusk 1998). Če bi se odločili za »Slovensko Istro«, torej za veliko začetnico, se postavlja vprašanje, ali potem z veliko začetnico zapisati tudi podobna imena: Slovenske Alpe, Avstrijska Štajerska, Slovenska Koroška, Slovensko Porabje, Slovensko Primorje. Zaenkrat je večina jezikoslovnih in zemljepisnih argumentov za pisanje z malo začetnico.

Omeniti velja še avstrijske dežele Avstro-Ogrske, ki so v zavesti Slovencev med vsemi ozemeljskimi delitvami Slovenije še vedno najbolj žive in zakoreninjene, čeprav so le ostanek administrativne delitve

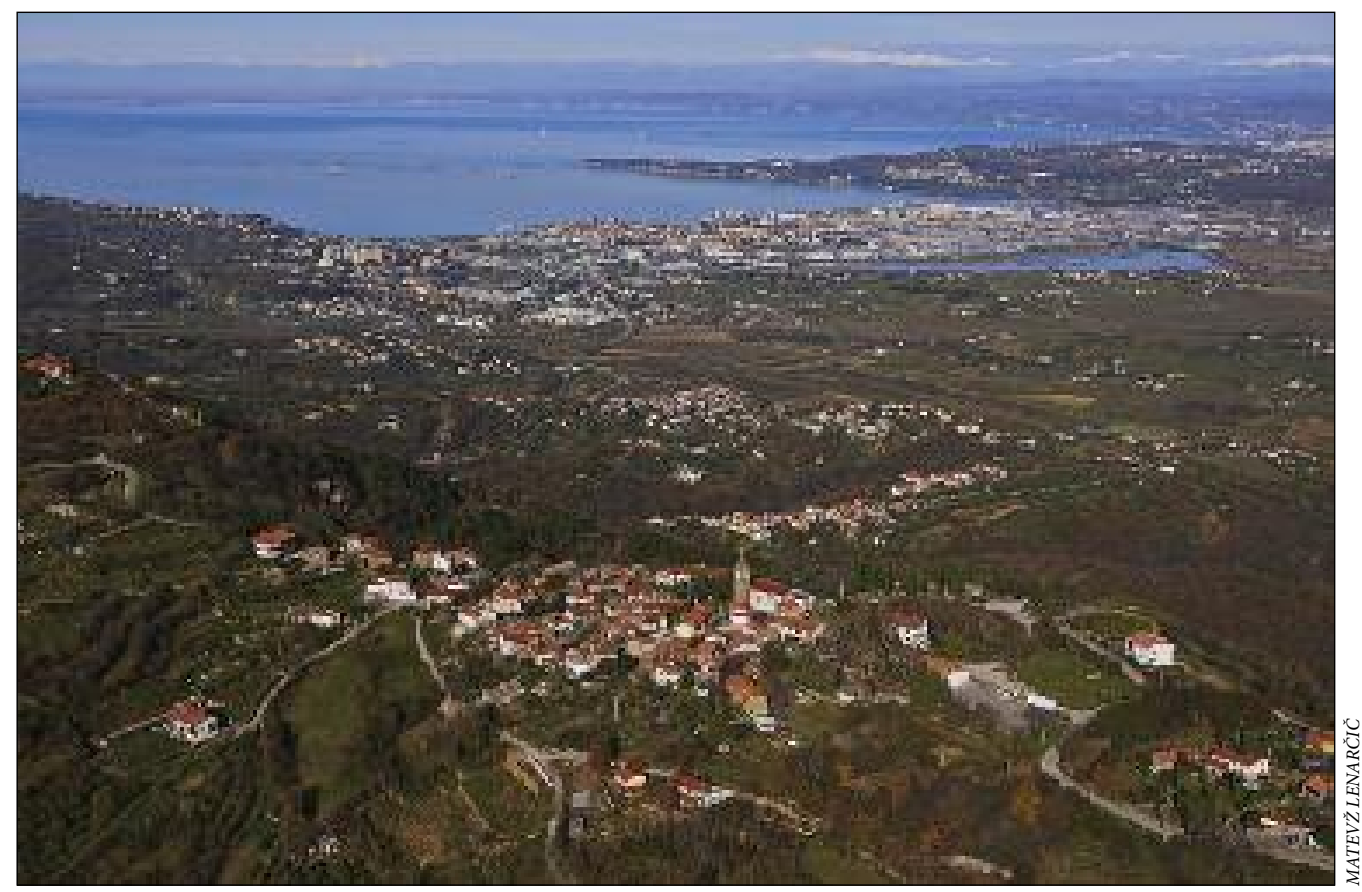

Slika 2: Panoramski pogled na del slovenske Istre z vasjo Pomjan v ospredju in Koprom v ozadju. 
že 100 let mrtve države. Ob začetku prve svetovne vojne so na ozemlje današnje Slovenije segale 4 avstrijske dežele: Štajerska (nem. Steiermark), Koroška (nem. Kärnten), Kranjska (nem. Krain) in Primorska (nem. Küstenland). Kljub temu pa se namesto Primorska pogosto uporablja tudi Avstrijska/avstrijska Primorska in iz tega izpeljana izraza Slovenska/slovenska Primorska oziroma Slovensko/slovensko Primorje. Tudi v tem primeru ni razloga za pisanje z veliko začetnico, saj je bil uradni naziv dežele »samo« Primorska oziroma Primorsko (slika 3), s pridevnikom slovenska/avstrijska pa samo krajevno opredeljujemo, za kateri del ozemlja blizu morja gre in ga ločimo od, recimo, hrvaškega ali italijanskega.

Z malo začetnico zapisana besedna zveza slovenska Istra se zagotovo nanaša le na del polotoka Istre, ki pripada Republiki Sloveniji in ga skupaj z njim sestavljata še hrvaška Istra v Republiki Hrvaški in italijanska Istra v Republiki Italiji. V tem primeru prva beseda sploh (še) ni del zemljepisnega imena, temveč ga zgolj natančneje določa, podobno kot je v primeru avstrijske Koroške.

$\mathrm{Na}$ Jezikovno svetovalnico je bilo v zvezi $\mathrm{z}$ obravnavano dilemo naslovljeno vprašanje, na katerega je bil podan naslednji odgovor (Jakop 2017): »V normativnih priročnikih je doslej bilo in je še kodificirano zemljepisno lastno ime Istra, pri čemer pridevnik slovenski/hrvaški ni del lastnega imena. To obliko imena izpričujejo tudi nekateri leksikoni in enciklopedije. Zagovorniki rabe velike začetnice pridevnika izhajajo iz prepričanja, da je ime geografske enote v resnici Slovenska/Hrvaška Istra. Komisija za standardizacijo

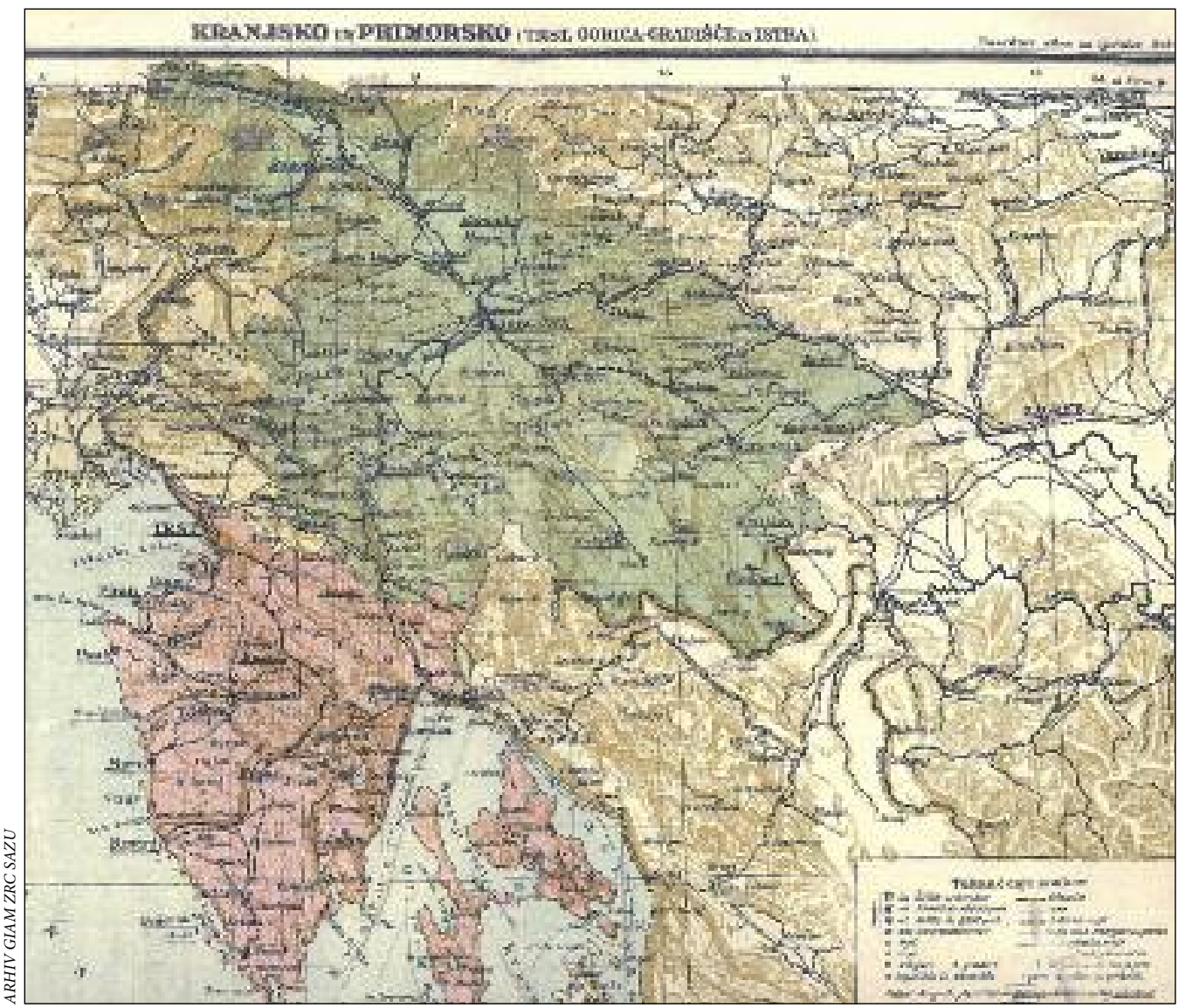

Slika 3: Zemljepisni atlas za ljudske šole s slovenskim jezikom iz leta 1904 potrjuje, da je bilo slovensko ime za avstrijsko deželo ob morju Primorsko, ne pa Primorje, Slovensko Primorsko ali Slovensko Primorje. 
zemljepisnih imen zaenkrat ne daje novih priporočil, ki bi upravičevala spremembo kodifikacije, vendar bi v prihodnje argumenti stroke (zlasti geografske) lahko vplivali na spremembo v imenu te zemljepisne danosti...«.

\subsection{Označevanje lege znotraj celin}

Tudi za geografe je pomembna dilema, ki jo je odprlo na Jezikovno svetovalnico naslovljeno vprašanje, zakaj se pri pojmu Severna Amerika obe besedi pišeta z veliko začetnico, pri pojmu jugovzhodna Azija pa ne (Dobrovoljc 2014). Še bolj podrobno je bilo poizvedovanje, kako se pišejo Vzhodna/vzhodna Evropa, Zahodna/zahodna Evropa, Srednja/srednja Evropa in Jugovzhodna/jugovzhodna Evropa. V časopisju naj bi povsem prevladoval zapis navedenih poimenovanj z malo začetnico, z malo so zapisana tudi v Leksikonu Sova iz leta 2006. Torej so obravnavana kot občna v smislu vzhodna Evropa kot vzhodni del Evrope. Vprašanje se sklicuje tudi na monografijo Slovenski eksonimi (Kladnik s sodelavci 2013), kjer so vsa ta imena zapisana $\mathrm{z}$ veliko začetnico in so kot takšna zemljepisna imena, ki se skladno s pravopisnimi pravili pišejo $\mathrm{z}$ veliko začetnico.

V odgovoru (Kladnik 2014b) je najprej navedeno, da se ob zgoraj naštetih evropskih zemljepisnih imenih pojavljajo še Južna Evropa, Severna Evropa, Jugozahodna Evropa in Severozahodna Evropa. Ugotovljeno je tudi, da so jezikovni uporabniki lahko resnično v zadregi, saj se pojavlja prekrivnost s poimenovanji, ki označujejo lego znotraj celine, torej Vzhodna/vzhodna Evropa.

Analogno členitvi Evrope se pojavljajo tudi delitve nekaterih drugih celin, na primer Afrike in Azije (Srednja ali Centralna Afrika, Srednja ali Centralna ali Notranja Azija, Vzhodna Afrika, Vzhodna Azija, Zahodna Afrika), Amerike (kjer imeni Severna Amerika in Južna Amerika označujeta celini znotraj enotne zemljine Amerike, pojavljajo pa se še izrazi Srednja ali Centralna Amerika, Medmorska Amerika, Karibska Amerika, Latinska Amerika, Angloamerika), in tudi Avstralije, kjer imeni Zahodna Avstralija in Južna Avstralija označujeta dve od osmih upravnih enot (držav in ozemelj) znotraj države Avstralije.

Kot zemljepisna imena, ki zahtevajo rabo velike začetnice, se torej pojavljajo poimenovanja regij, ki so posledica členitve posameznih celin na geografsko zaokrožene enote $\mathrm{z}$ natančno določenim pripadajočim ozemljem in s tem natančno opredeljenim obsegom. Tak pristop je še posebej uveljavljen v šolski geografiji, kjer je, ob poenostavljanju zaradi lažjega poučevanja, raba velikih začetnic za označevanje posameznih delov celin tako rekoč »zapovedana".

Zadeva pa ni ravno preprosta, saj se že v sami geografiji pojavljajo različne členitve, ki imajo za posledico oblikovanje različno obsežnih, vendar enako poimenovanih regij, še bolj pa se zaplete, če upoštevamo (raznovrstne) členitve, ki jih uporabljajo nekatere druge stroke in mednarodna telesa, kakršni sta Organizacija združenih narodov ali na primer Južnoafriška razvojna skupnost (Southern African Development Community, kratko SADC).

$\mathrm{V}$ praksi se torej politično oblikovane in naravnogeografske regije praviloma ne ujemajo, zato je po našem mnenju bolj na mestu raba male začetnice, s katero okvirno le nakazujemo del celine glede na lego znotraj nje in ob tem njegovega obsega natančneje ne opredeljujemo. Zato tudi raziskovalno usmerjeni geografi v vsakdanji »znanstvenoraziskovalni« praksi pri označevanju delov celin praviloma uporabljamo male začetnice.

Če povedano ponazorimo z dobro znanim pojmom Srednja/srednja Evropa, lahko kaj hitro pridemo do spoznanja, da je to območje kot regija precej nedorečeno, saj si ga mnogi razlagajo vsak po svoje, zato je težko govoriti o ozemeljsko poenoteni regiji, katere poimenovanje bi imelo značaj lastnega imena in zahtevalo rabo velike začetnice.

\subsection{Večbesedna gorska imena}

Sorodna razmerja glede rabe velike in male začetnice se pojavljajo tudi pri večbesednih gorskih imenih ali oronimih. Posebej pogosta so v primerih prostranih gorovij, ki se lahko razprostirajo prek ozemelj 
več držav. V Jezikovni svetovalnici sta se pojavili vprašanji glede Karpatov in Alp. Prvo se je glasilo: "Pri pisanju strokovnega članka iz geografije se mi poraja vprašanje, kako zapisati zemljepisna imena kot so npr. Zahodni Karpati ali Francoske Alpe? Torej, oboje z veliko začetnico ali ne? «, drugo pa: »Kako pišemo zvezo Vzhodne/vzhodne Alpe? Vem, da pišemo oboje z veliko pri zvezah Julijske Alpe in Kamniške Alpe...«.

Odgovor na prvo vprašanje (Dobrovoljc 2013b) sporoča, da je besedna zveza Zahodni Karpati zemljepisno lastno ime, ki označuje zahodni del gorovja Karpati in je kot tako živo tako v domači kot mednarodni rabi. Zveza francoske Alpe pa ni lastnoimenska, saj ne glede na to, da poznamo različne Alpe (izraz je že sam po sebi lastno ime), na primer Karnijske, Julijske, Bernske in podobno, med njimi ni francoskih. Lahko bi rekli, da gre za del Alp, ki se razrostira v Franciji. Tudi v Sloveniji imamo na primer slovenske Alpe, ki jih sestavljajo Julijske Alpe, Kamniško-Savinjske Alpe, Karavanke ... Odgovor na drugo vprašanje (Kladnik 2014a) dilemo rabe velike ali male začetnice še dodatno osvetli. Najprej je navedeno, da obe sestavini imena Vzhodne Alpe pišemo z veliko začetnico, saj gre za zemljepisno ime. Alpe se namreč po najbolj grobi členitvi delijo na Vzhodne Alpe vzhodno od črte Bodensko jezero-dolina Rena-Splügenpass-dolina reke Liro-Comsko jezero (Lago di Como) in Zahodne Alpe zahodno od te črte. Meja je povsem natančno opredeljena, sčimer je natančno določen tudi obseg obeh glavnih sestavnih delov Alp. Razmejitev je tradicionalna in dobro zakoreninjena.

\subsection{Podomačena večbesedna naselbinska imena}

$\mathrm{Na}$ Jezikovno svetovalnico je prispelo tudi nekoliko manj zahtevno vprašanje, ali se v neprvi sestavini, ki ni mesto, vas, trg, selo ali naselje, $v$ večbesednem naselbinskem imenu, ki je prevedeno v slovenščino, uporablja velika ali mala začetnica? Kot hipotetičen primer se navaja mesto, ki bi se imenovalo Korintska Vrata/Korintska vrata.

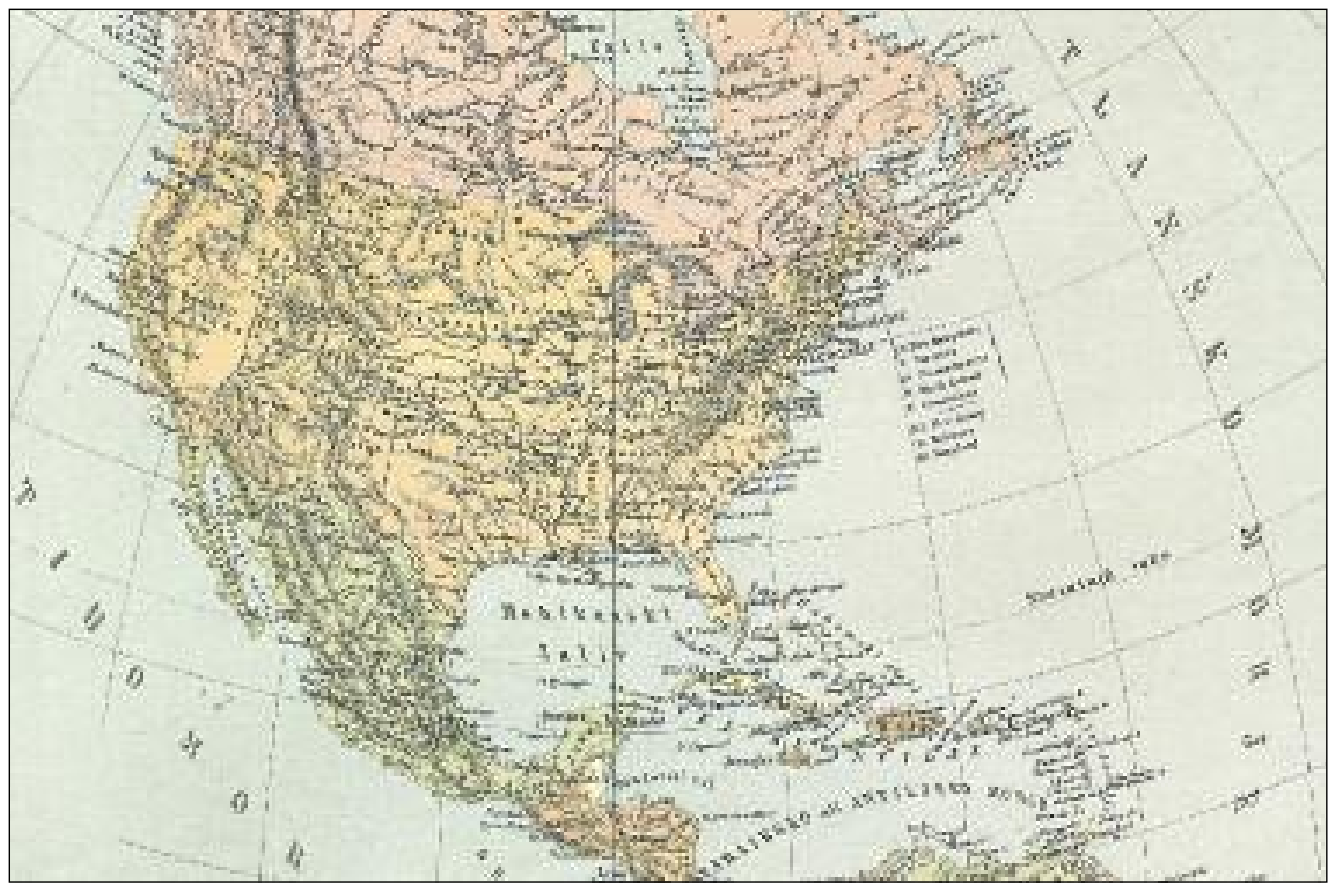

Slika 4: V Atlantu, prvem atlasu sveta v slovenskem jeziku, je Matej Cigale New York zapisal kot Novi Jork. 
V odgovoru (Dobrovoljc 2013a) je najprej navedeno, da se tuja naselbinska imena v slovenščino prevajajo le izjemoma. Iz zgledov v pravopisnih pravilih (člen 205: Nižji Novgorod, Frankfurt ob Majni/Odri, Dunajsko Novo mesto, Češke Budjejovice, Špindlerjev Mlin) je razvidno, da sta pri večbesednih imenih prevedena le občnoimenska sestavina in predlog, lastnoimenska sestavina pa je prilagojena slovenskemu pisnemu sistemu. To potrjujejo tudi imena, ki jih v pravilih ni, na primer ruski Rostov ob Donu, češka Kutna Gora, nemški Zahodni Berlin ... Nato je pojasnjeno, da se tudi prevedena naselbinska imena pišejo po pravilih za slovenska imena (člen 69), torej bi se zgoraj naveden hipotetičen primer zapisal v obliki Korintska Vrata. Sledi še opozorilo, da merila za podomačevanje oziroma prevajanje naselbinskih imen niso natančno določena, zato so v rabi pogosta neskladja, kot na primer New York proti Novi Amsterdam.

Dodamo lahko, da zadnji navedeni primer ni najbolj posrečen, saj v bistvu ne gre za imensko dvojnico, ampak različni imeni istega naselja, od katerega se je starejše (Nieuw Amsterdam/New Amsterdam) pogosto prevajalo, novejše New York, do preimenovanja je prišlo leta 1664, pa v obliki Novi Jork/Novi York (slika 4) znatno redkeje. Boljša primera prevedenih večbesednih imen sta Novi Orleans in Sveti Frančišek za New Orleans oziroma San Francisco, ki ju najdemo v Atlantu, prvem slovenskem atlasu sveta (Atlant 1869-1877), za katerega je imena priredil Matej Cigale in je v snopičih izhajal v letih 1869-1877 (Urbanc s sodelavci 2006). Nasploh je bila praksa v zgodnjem obdobju prevzemanja zemljepisnih imen v slovenščino prevajanju precej bolj naklonjena.

Glede prevajanja zemljepisnih imen je treba opozoriti, da resolucije Združenih narodov nadaljnje nekritično prevajanje naselbinskih in tudi nenaselbinskih imen ter s tem povečevanje števila eksonimov odločno odsvetujejo (Kladnik 2007).

\subsection{Vzdevki oziroma nadomestna imena}

Pri večbesednih zemljepisnih imenih se nakazuje težnja po rabi velike začetnice v vseh imenskih sestavinah, povsem drugačno smer pa je mogoče zaznati pri nadomestnih imenih oziroma vzdevkih. V zvezi z njimi je bila dolgo prisotna dilema ustreznega pisanja, denimo Črna celina ali črna celina za Afriko, Novi svet ali novi svet za Ameriko, Dežela tisočerih jezer ali dežela tisočerih jezer za Finsko (slika 5), Dežela vzhajajočega Sonca ali dežela vzhajajočega Sonca za Japonsko, Švica Bližnjega vzhoda ali švica Bližnjega vzhoda za Libanon ter Striček Sam/striček Sam-Dežela pogumnih/dežela pogumnih-Obljubljena dežela/obljubljena dežela-Veliki satan/veliki satan za Združene države Amerike. Vzdevki se ne pojavljajo le za imena celin in držav, ampak tudi druge zemljepisne pojave, zlasti mesta, na primer Večno mesto/večno mesto za Rim in Severne Benetke/severne Benetke za Stockholm.

Na drugi strani na primer Sveti sedež ni nadomestno ime za Vatikan, ampak njegovo alternativno ime, ki ima skupaj z imensko različico Vatikanska mestna država status uradnega kratkega in uradnega polnega imena (Kladnik in Perko 2013).

Jezikoslovci ugotavljajo, da se je pri nadomestnih imenih, podobno kot pri nekaterih nekoč uveljavljenih lastnih imenih, pisanje $\mathrm{z}$ veliko začetnico že umaknilo zapisu $\mathrm{z}$ malo začetnico, na primer stari svet za Evropo, Azijo in Afriko skupaj, novi svet za Ameriko in Avstralijo, stara celina za Evropo, kar potrjujejo tudi poimenovanja iz novejšega časa, na primer bela celina za Antarktiko. Ta težnja se nadaljuje, kar dokazujejo poimenovanja, ki so v veljavnem Slovenskem pravopisu (2001) zapisana $\mathrm{z}$ veliko začetnico, njihova dejanska raba pa že izkazuje drugačno normo (Dobrovoljc in Jakop 2011).

$\mathrm{Ob}$ tem je treba opozoriti na neupravičeno izenačevanje poljudnih poimenovanj $\mathrm{z}$ nadomestnimi in skrajšanimi imeni, ki v dosedanjih pravopisnih priročnikih še niso bila razlikovalno definirana. Čeprav med »poljudna poimenovanja « uvrščamo splošno razširjena poimenovanja, ki so pogosto (a ne vedno) krajša, med jezikovnimi uporabniki razširjena in se navadno razlikujejo od uradnih imen, jih ne moremo enačiti s skrajšanimi ali nadomestnimi imeni, ki ohranjajo status lastnih imen, na primer Barje za Ljubljansko barje, Otok za Veliko Britanijo (Dobrovoljc in Jakop 2011). 


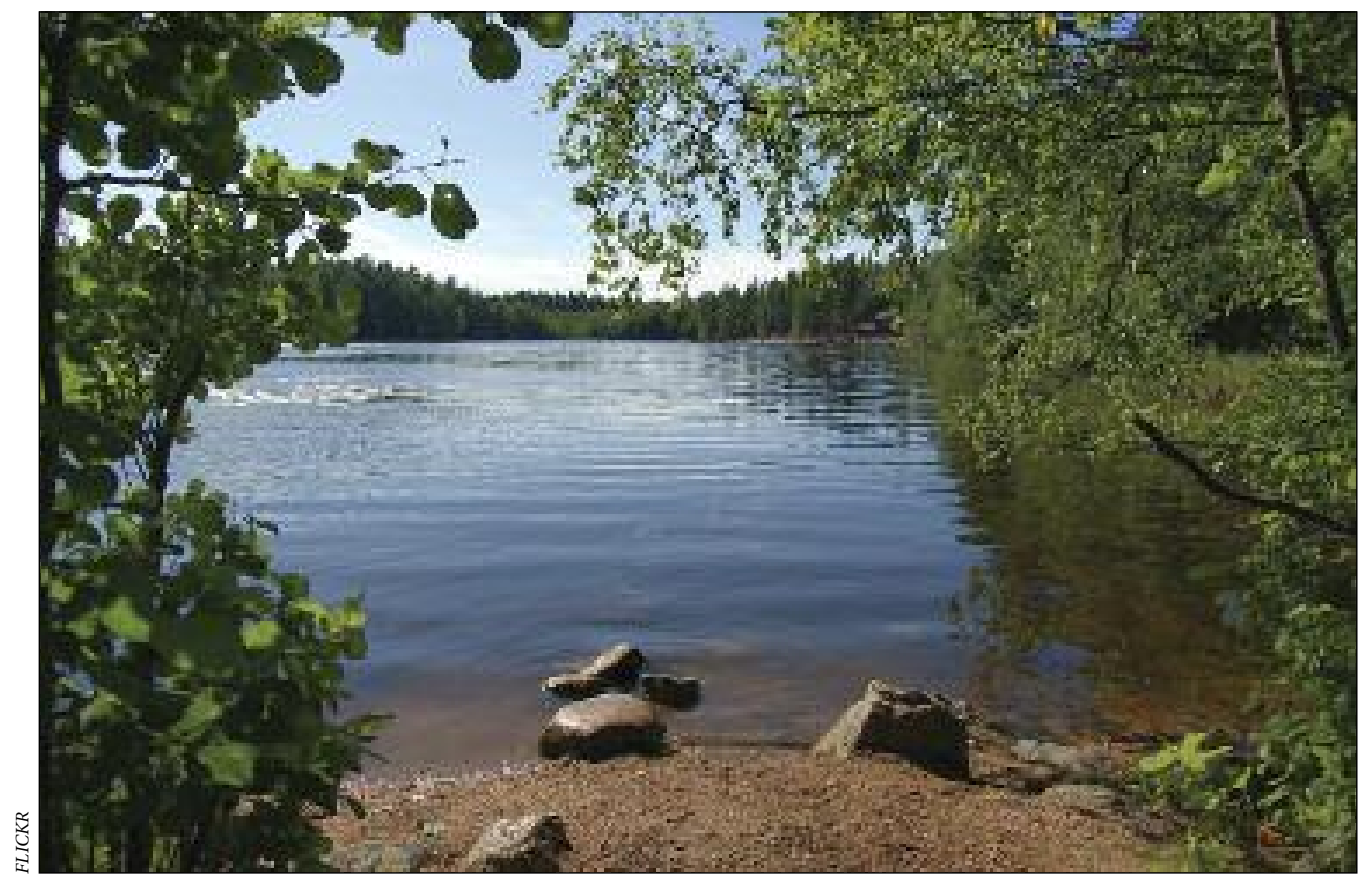

Slika 5: Zaradi skoraj 188.000 tamkajšnjih jezer, večjih od $500 \mathrm{~m}^{2}$ (medmrežje 1), ni čudno, da se je Finske oprijel vzdevek dežela tisočerih jezer.

\subsection{Imena delov mestnih naselij in imena zaselkov}

Kot zadnjo težavno tematiko v zvezi z ustrezno rabo velike in male začetnice izpostavljamo njuno neenotno rabo pri večbesednih imenih zaselkov in delov mestnih naselij. Na eni strani se za zaselke uporablja pravilo o pisanju naselbinskih imen, torej se z izjemo občnoimenskih sestavin mesto, trg, vas, vesca, selo, sela, selce, naselje, vse imenske sestavine pišejo z veliko začetnico (na primer Doljnje Nekovo, Hrastniš̌ka Grapa, Kravja Dolina, Na Župi, Žilavčev Breg, vendar Jetrno selo, Podjetniško naselje Kočevje in Pasja vas), na drugi pa za dele mestnih naselij povsem nelogično pravilo o pisanju nenaselbinskih imen, kjer se razen uvodne besede vse druge imenske sestavine, če ne gre za lastno ime, pišejo z malo začetnico (na primer Zelena jama, Rožna dolina, Nove Poljane/Nove poljane, Mariborska metropola). Med dele krajev spadajo tudi mestne četrti (na primer Tabor, Koroška vrata, Nova vas) in mestni parki (na primer Tivoli, Mestni park, Miklošičev park) ter imena stanovanjskih sosesk (na primer Bratovževa ploščad, Viška sončava).

Nejasnosti se zavedajo tudi jezikoslovci, kar potrjuje naslednji zapis (Dobrovoljc 2012b, 54): »Konkretna vprašanja jezikovnih uporabnikov razkrivajo, da je mnogim težavno nedvoumno definirati pojma naselbinsko oziroma nenaselbinsko ime. Glede na to, da je po definiciji $v$ SSKJ beseda naselbina $v$ pome$n u$ 'naselje, zaselek' zastarela, kar načeloma pomeni, da jo kot živo srečujemo le v strokovnem jeziku, je praktično razlikovanje na ravni naselbina - nenaselbina pogosto težavno. Še zlasti, ker po tej kategorizaciji spadajo med nenaselbinska imena tudi deli naselbin in se vopozicijo postavljajo poimenovanja Zali Log (naselje v povirju Selške Sore) in Mestni log (del Ljubljane) oziroma Rožna Dolina (naselje pri Novi Gorici) in Rožna dolina (del Ljubljane)...«.

Predvidoma bodo v novem pravopisu tovrstna neskladja odpravljena. Skladno z novimi pravili naj bi se vse sestavine naselbinskih imen, ki bodo na novo opredeljena, praviloma pisale $\mathrm{z}$ veliko začetnico. 


\section{Sklep}

Pričakovati je, da bo z novim slovenskim pravopisom raba zemljepisnih imen za splošno javnost olajšana, kar velja še posebej zaradi načrtovanih sprememb pravil pri rabi velike in male začetnice. Ta odpravljajo izjeme pri rabi velike začetnice v večbesednih naselbinskih imenih $\mathrm{z}$ občnoimenskimi sestavinami mesto, vas, selo, trg in naselje, ki se naj bi po novem, tako kot v večini evropskih jezikov, pisala $z$ veliko začetnico. Prav tako naj bi se $z$ veliko začetnico pisala večbesedna zemljepisna imena mestnih delov, v obeh primerih pa bodo še vnaprej izjeme le morebitni neprvi oziroma vmesni predlogi (na primer Nova Vas pri Ptuju). Pri večbesednih nenaselbinskih imenih bo z veliko začetnico vselej zapisana prva imenska sestavina, začetnica drugih sestavin pa se bo ravnala po tem, ali ima ta občni značaj ali je lastno ime. $\mathrm{V}$ prvem primeru bo zapisana $\mathrm{z}$ malo začetnico, $\mathrm{v}$ drugem pa $\mathrm{z}$ veliko.

Razširitev velike začetnice na vse sestavine nenaselbinskih imen bi pomenila precejšen obrat od dosedanje klasifikacije (Šmarna gora > Šmarna Gora, Goriška brda > Goriška Brda, Ljubljansko barje $>$ Ljubljansko Barje, Bela krajina $>$ Bela Krajina), hkrati pa bi s tem uzakonili način pisanja, ki je v praksi ustaljen v več jezikih, zanj pa se zavzema tudi vse več slovenskih jezikoslovcev in geografov. Vendar ob navdušenju nad poenostavitvijo ne smemo prezreti dejstva, da so jezikoslovci tako zapisovalno načelo $\mathrm{v}$ preteklosti že udejanili, a je bilo zaradi obsežnosti in neuspešnosti zavrnjeno (Dobrovoljc in Jakop 2011; Dobrovoljc 2012b).

Mednarodnim priporočilom bodo v večji meri prilagojena tudi pravila o prevzemanju tujih besed $\mathrm{v}$ slovenščino, kar pomeni, da bo skladno $\mathrm{z}$ upoštevanjem pravil mednarodnih latiničnih prečrkovanj v manjši meri predvideno zdaj skoraj zapovedano domačenje lastnih imen, v izvirni obliki zapisanih v nelatiničnih pisavah ali ideogramih.

Nekatera lastna imena, zemljepisna niso nikakršna izjema (tako se je na primer po pokrajini Kras mednarodno uveljavil pojem kras oziroma karst za pokrajine iz karbonatnih kamnin ter z značilnimi površinskimi in podzemeljskimi pojavi), z apelativizacijo izgubijo značilno identifikacijsko oziroma individualizacijsko vlogo, kar vpliva na njihov zapis z malo začetnico, pogosto jih tudi pisno prilagodimo slovenščini (Dobrovoljc 2012a).

Iz zapisanega lahko sklenemo, da je ustrezna raba zemljepisnih imen razmeroma zapletena in zahteva usklajenost jezikoslovcev, geografov, kartografov in drugih vpletenih strokovnjakov. Pomemben prispevek k poenotenju rabe in s tem manjši zmedi je standardizacija zemljepisnih imen, pri čemer smo v Sloveniji zaradi pomanjkanja sredstev za ta namen za zdaj naredili le skromne korake. Pred standardizacijo je namreč potreben temeljit jezikovni in pomenski pretres posameznih imen.

Ker razen za imena držav (Slovenski standard ... 2016), naselij na ozemlju Republike Slovenije ter pomembnejših slovenskih pokrajin, gorovij, vrhov, vodotokov in jezer standardizacija še ni bila opravljena (Furlan s sodelavci 2008), je ob snovanju novega slovenskega pravopisa treba poskrbeti za ustrezen nabor pojmov za njegov slovarski del, pa tudi za ustrezne ponazoritvene primere v pravilih. Vključena naj bi bila vsa imena neodvisnih držav in najpomembnejših odvisnih ozemelj ter vsa glavna mesta vključno z imeni njihovih prebivalcev, največja mesta, sistematizirana imena upravnih enot, največja jezera, najdaljše reke, najvišji in najmogočnejši slapovi, največja pogorja in najvišji vrhovi, največji otoki in glavni polotoki, denimo po deset v svetovnem merilu za vsak pojav in vsa bolj znana pri nas.

Ob njih naj bi bila zabeležena tudi imena, ki so pridobila občnoimenski značaj, na primer Angora (iz tega imena izhajajo angora volna ter angora mačka in zajec; zdaj Ankara), Florenca (iz tega imena sta izpeljana samostalnik florentinec in pridevnik florentinski, ki označuje vrsto zrezka, omake, posode in še česa; zdaj Firence), Jersey (v podomačeni obliki džersi, vrsta mehke, pogosto elastične tkanine, spletene iz volne, bombaža, svile ali sintetičnih vlaken), Shetlantski otoki (iz tega imena sta izpeljana samostalnik šetland, ki označuje bodisi gladko volno angleških ovc bodisi tkanino, ter pridevnik šetlandski, ki označuje vrsti psa in konja; originalno Shetland Islands) in Solnograd (iz njega sta izpeljana arhaični eksonim za avstrijsko pokrajino Solnograško oziroma Solnograška, pa tudi pridevnik solnograški, na katerega se navezujejo znameniti žličniki; zdaj Salzburg). 
Zahvala: Prispevek temelji na raziskovalnem programu Geografija Slovenije (P6-0101), ki ga financira Javna agencija za raziskovalno dejavnost Republike Slovenije.

\section{Viri in literatura}

Atlant. Slovenska matica. Ljubljana, 1869-1877.

Bizjak Končar, A., Dobrovoljc H., Weiss, P. 2014; »Goriška Brda« in »Brda« ter »Sončevi« in »sončni« žarki. Jezikovna svetovalnica. Medmrežje: https://svetovalnica.zrc-sazu.si/topic/515/goriška-brdain-brda-ter-sončevi-in-sončni-žarki (28.11.2017).

Dobrovoljc, H. 2012a: Pisanje imen izdelkov in znamk. Pravopisna stikanja: razprave o pravopisnih vprašanjih. Ljubljana.

Dobrovoljc, H. 2012b: Pisanje začetnice v predložnih lastnih imenih. Pravopisna stikanja: razprave o pravopisnih vprašanjih. Ljubljana.

Dobrovoljc, H. 2013a: Prevedena večbesedna naselbinska imena in raba začetnice. Jezikovna svetovalnica. Medmrežje: http://isjfr.zrc-sazu.si/sl/svetovalnica/prevedena-vecbesedna-naselbinska-imena-inraba-zacetnice\#v (28.11.2017).

Dobrovoljc, H. 2013b: Raba začetnice v imenih »Zahodni Karpati« in »francoske« Alpe«. Jezikovna svetovalnica. Medmrežje: http://isjfr.zrc-sazu.si/sl/svetovalnica/raba-zacetnice-v-imenih-zahodni-karpati-in-francoske-alpe\#v (18.11.2017).

Dobrovoljc, H. 2014: Pisanje večbesednih zemljepisnih imen: „Severna Amerika«, »ugovzhodna Azija«. Jezikovna svetovalnica. Medmrežje: http://isjfr.zrc-sazu.si/sl/svetovalnica/pisanje-vecbesednihzemljepisnih-imen-severna-amerika-jugovzhodna-azija\#v (28. 11.2017).

Dobrovoljc, H., Jakop, N. 2011: Sodobni pravopisni priročnik med normo in predpisom. Ljubljana.

Dobrovoljc, H., Jakop, N. (ur.) 2012: V iskanju soglasja. Pravopisna stikanja: razprave o pravopisnih vprašanjih. Ljubljana.

Furlan, M., Gložančev, A., Kladnik, D., Perko, D., Šivic-Dular, A. 2008: Imenik zemljepisnih imen Državne pregledne karte Republike Slovenije v merilu 1:250.000. Državna pregledna karta Republike Slovenije $1: 250.000$ : standardizirana slovenska zemljepisna imena. Ljubljana.

Gams, I. 1990: O imenu obalne regije. Geografski vestnik 62.

Geršič, M. 2017: Changing denotations of selected Slovenian choronyms. Acta geographica Slovenica 57-1. DOI: https://doi.org/10.3986/AGS.4600

Gigafida 2017. Medmrežje: http://www.gigafida.net/ (20.10.2017).

Jakop, N. 2017: Pisanje zemljepisnega imena »slovenska Istra«. Jezikovna svetovalnica. Medmrežje: http://isjfr.zrc-sazu.si/sl/svetovalnica/pisanje-zemljepisnega-imena-slovenska-istra\#v (29.11.2017).

Jezikovna svetovalnica. Inštitut za slovenski jezik Frana Ramovša ZRC SAZU. Ljubljana, 2017. Medmrežje: https://svetovalnica.zrc-sazu.si/ (15. 10.2017).

Kladnik, D. 1996: Naravnogeografske členitve Slovenije. Geografski vestnik 68.

Kladnik, D. 2006: Tuja zemljepisna imena v slovenskem jeziku; razvojni vidiki in problematika njihove rabe. Doktorsko delo, Oddelek za geografijo Filozofske fakultete Univerze v Ljubljani. Ljubljana.

Kladnik, D. 2007: Pogledi na podomačevanje tujih zemljepisnih imen. Georitem 2. Ljubljana.

Kladnik, D. 2014a: Kako pišemo zvezo »Vzhodne Alpe«? Jezikovna svetovalnica. Medmrežje: http://isjfr.zrc-sazu.si/sl/svetovalnica/kako-pisemo-zvezo-vzhodne-alpe\#v (18. 11.2017).

Kladnik, D. 2014b: Zemljepisna imena pokrajin in označevanje lege znotraj celin. Jezikovna svetovalnica. Medmrežje: https://svetovalnica.zrc-sazu.si/topic/582/zemljepisna-imena-pokrajin-in-ozna\%C4\% 8Devanje-lege-znotraj-celin (24. 10.2018).

Kladnik, D., Bole, D. 2012: The life of Slovenian exonyms and their familiarity in the professional community. Acta geographica Slovenica 52-2. DOI: https://doi.org/10.3986/AGS52204 
Kladnik, D., Ciglič, R., Hrvatin, M., Perko, D., Repolusk, P., Volk Bahun, M. 2013: Slovenski eksonimi. Geografija Slovenije 24. Ljubljana.

Kladnik, D., Crljenko, I., Čilaš Šimpraga, A., Geršič, M. 2017: A comparison of Croatian and Slovenian exonyms. Acta geographica Slovenica 57-1. DOI: https://doi.org/10.3986/AGS.4653

Kladnik, D., Perko, D. 2007: Problematična imena držav v slovenskem jeziku. Geografski vestnik 79-2.

Kladnik, D., Perko, D. 2013: Slovenska imena držav. Geografija Slovenije 25. Ljubljana.

Kladnik, D., Perko, D. 2015: Problematika poimenovanja držav in odvisnih ozemelj. Pravopisna razpotja: razprave o pravopisnih vprašanjih. Ljubljana.

Kladnik, D., Perko, D. 2017: Ustreznejša raba slovenskih zemljepisnih imen. Geografski vestnik 89-2. DOI: https://doi.org/10.3986/GV89205

Klinar, K., Geršič, M. 2014: Traditional house names as part of cultural heritage. Acta geographica Slovenica 54-2. DOI: https://doi.org/10.3986/AGS54409

Leksikon Sova. Ljubljana, 2006.

Medmrežje 1: https://www.worldatlas.com/articles/which-country-has-the-most-lakes.html (19. 10. 2018).

Perko, D., Jordan, P., Komac, B. 2017: Exonyms and other geographical names. Acta geographica Slovenica 57-1. DOI: https://doi.org/10.3986/AGS.4891

Perko, D., Kladnik, D. 2017: Slovenian exonyms in North America. Acta geographica Slovenica 57-1. DOI: https://doi.org/10.3986/AGS.47777

Preglednica eksonimov 2014: Medmrežje: http://giam.zrc-sazu.si/sl/zbirka/zemljepisna-imena\#v (15. 10.2017).

Repolusk, P. 1998: Koprska brda. Slovenija - pokrajine in ljudje. Ljubljana.

Slovenski pravopis. Ljubljana, 2001.

Slovenski standard SIST ISO 3166-2. Kode za predstavljanje imen držav in njihovih podrejenih enot 2. del: Kode podrejenih enot države. Slovenski inštitut za standardizacijo. Ljubljana, 2016. Medmrežje: http://ecommerce.sist.si/catalog/project.aspx?id=449fe421-2d64-4b81-8322-b719b7fad341 (18. 10.2018).

Urbanc, M., Fridl, J., Kladnik, D., Perko, D. 2006: Atlant and slovene national consciousness in the second half of the $19^{\text {th }}$ century. Acta geographica Slovenica 46-2. DOI: https://doi.org/10.3986/AGS46204

Vodopivec, F. 2000: Revija Istrske teme, ocena letnikov 1998 in 1999. Medmrežje: http://www.istra-nasa.si/ dr-franc-vodopivec-o-listu-istrske-teme/ (19.10.2017).

\section{Summary: Capitalization and other issues in writing Slovenian geographical names}

(translated by Drago Perko)

The article is a continuation of the article, published in Geografski vestnik 89-2 in 2017. It was devoted to more complex aspects and examples of the use of Slovenian geographical names, mostly exonyms. This second discussion is primarily dedicated to capitalization in multiword Slovenian geographical names, Slovenianizing multiword foreign geographical names, multiword names of parts of towns and villages, and capitalization of nicknames or other descriptive names (e.g., Dark Continent, land of a thousand lakes). The proper use of the upper-case and the lower-case is quite exacting in the valid Slovenian normative guide (Slovenian Ortography).

In general, the proper handling of geographical names is complicated, although many feel that they can easily handle this topic. This is also why in practice there are countless examples of non-systematic and inconsistent use. Nevertheless, the use of geographical names in Slovenian is becoming increasingly uniform. Unification of the use of domestic and foreign geographical names in accordance with the resolutions and recommendations of the United Nations Group of Experts on Geographical Names represented in Slovenia by the Commission for the Standardization of Geographical Names of the 
Government of the Republic of Slovenia - is one of the most pressing issues for the modern language norm. International standardization recommendations for writing geographical names are often in conflict with linguistic practice and contrary to the principles of a language, which is completely unacceptable.

This article draws attention to some open issues in the use of currently inconsistent or disputed geographical names in order to contribute to further improvement of the situation in this area. We have encountered disputed and inconsistent names for many years when preparing atlases and maps, editing publications, and participating in shaping the rules for the emerging new Slovenian normative guide.

In order to quantify the subject, we analyzed the frequency of occurrences of geographical names and their variants in the Gigafida language corpus, an electronic collection of authentic Slovenian texts containing almost 1.2 billion words. We also examined the records in the Language Advisory Service of the ZRC SAZU Fran Ramovš Slovenian Language Institute and found many detailed records on this topic. The way individual exonyms are represented and recorded in Slovenian reference atlases of the world is presented in a exhaustive table of exonyms.

It is expected that the new Slovenian normative guide will facilitate the use of geographical names for the general public, especially because of changed rules on using capitalization and international recommendations in more customized rules on the use of foreign lexemes in Slovenian. The names of the most important geographical phenomena are expected to be more systematically presented in the dictionary part of the guide. The materials discussed will also be a good source for the necessary standardization of the bulk of Slovenian geographical names that are still not standardized. 